\title{
Effect of Shatavari (Asparagus recemosus) on Milk Production in Lactating Buffaloes
}

\author{
S.C. Jingar ${ }^{1 *}$, Rachana Sharma ${ }^{2}$, Pankaj Lawania ${ }^{1}$, Ajesh Kumar ${ }^{3}$, \\ H. Bugaliya ${ }^{1}$ and Shiv Murat Meena ${ }^{1}$ \\ ${ }^{1}$ LPM, Krishi Vigyan Kendra, Chittorgarh, Rajasthan, India \\ ${ }^{2}$ NDRI, Karnal, Haryana, India \\ ${ }^{3}$ Subject Matter LPM, Krishi Vigyan Kendra, Churu, Rajasthan, India \\ *Corresponding author
}

A B S T R A C T

\section{Key w o r d s \\ Shatavari, \\ Milk production, Lactating buffaloes \\ Article Info \\ Accepted: \\ 24 June 2018 \\ Available Online: \\ 10 September 2018}

An On Farm Trial was conducted to evaluate the effect of shatavari (Asparagus recemosus) on milk production in lactating buffaloes which were parturated 1 to 4 months before commencement of trial. Total 20 lactating buffaloes were selected and fed $50 \mathrm{gm}$ powder of shatavari roots in concentrates once in a day for a period of 180 days. The milk production was increased $0.60+0.27 \mathrm{~kg}(9.67 \%)$ daily respectively as compared to their previous production. Increase in the income by feeding shatavari came to Rs. 12.00/day/animal and B:C ratio was found 1:2.28. From the above results it was concluded that shatavari is effective for increase in milk production and beneficial for economic milk production.

\section{Introduction}

Shatavari act as antiseptic, astrigent diuretic and galactogogue properties. Roots contains saccharine and mucilagenous substances in large proportion. It helps in improving digestibility, increase milk after calving, help for mammary gland development, hastens letting down time, stimulate lactiferous tissues and keeps udder and treats in smooth condition (Somkuwar et al., 2005). However, very few attempts have been made to test the effect of shatavari on milk production in field conditions. An attempt was therefore, made to investigate the effect of shatavari feeding on the productivity of buffaloes and cows in field condition.

Asparagus racemosus is most frequently used in indigenous medicine. The name Shatavari means curer of a hundred diseases (shat means hundred and vari means curer) and it is also known as Satavar and Shatmuli. The leaves are alike pine needles, small and uniform and the flowers are white and have small spikes. It is a common species of asparagus under Liliaceae family distributed throughout India with 1 to $2 \mathrm{~m}$ in height. The genuses 
Asparagus contains about 300 species around the world and out of these 22 species are found in the India. Asparagus racemosus is the one most commonly used herb in traditional medicine due to the presence of steroidal saponins and sapogenins in various parts of a plant (Krishana et al., 2005). Traditionally it is used as a health tonic and common Indian home remedy used as a rejuvenator, promoter of strength, breast milk and semen. It is also used for cough, dyspepsia, edema, rheumatism, chronic fevers, aphrodisiac, cooling tonic antispasmodic, diarrhea and dysentery. It is also used for enhancing milk production in freshly parturient and lactating woman (Chopra and Simon, 2000). The general pharmacology of shatavari are galactogogue and mammogenic, it enhances the blood prolactin level and stimulazes the cellular division of mammary gland (Kumar et al., 2008).

\section{Materials and Methods}

The present study was conducted to evaluate the effect of shatavari feeding on milk production in dairy animals. Based on the observation and conclusion of PRA techniques of village Lambiya and Laxmipura, Panchayat Samitee of Ganghar, planned to organize the On Farm Trial (FLD) on effect of supplementary feeding of Shatavary roots powder on milk production performance of lactating buffaloes which were parturated 1 to 4 months in the period from 2015-16. Total 20 lactating buffaloes were selected. The selecting buffaloes were fed 50 grams per day per buffalo supplementary feeding of Shatavary roost powder with balance concentrate ration for the period of 180 days.

The milk yield was recorded for individual animals with fair degree of precision during the visit at fortnightly interval to the farmer's field.

\section{Results and Discussion}

Resutls of shatavari feeding on milk production in buffaloes presented in Table 1. the data revealed that during pre shatavari supplementation period the average milk production was $6.20+0.20 \mathrm{~kg} /$ day in buffaloes. Following the supplementation of shatavari, the milk production in buffaloes increased by 9.67 per cent $(0.60+0.27$ $\mathrm{kg}$ /day).During treatment period. Similar findings were reported by Samkuwar et al., (2005) who found that shatavari induced significant increase $(10.43 \%)$ in daily milk production in buffaloes in treatment group and also similar feeding reported by Tanwar et al., (9\%). Expenditure on feeding of shatavari and income from extra milk were taken into consideration for economic evaluation of shatavari feeding. Table 2 revealed that supplementation of shatavari in buffalo returned net income by Rs. 12.00/day/buffalo. The cost benefit ratio (B:C ratio) were 1:2.28 in buffalo Thus, it may be concluded that shatavari has lactogenic properties to improve the milk production and economic for feeding to dairy animals.

Table.1 Effect of Shatavari feeding on milk production in lactating buffaloes

\begin{tabular}{|l|l|l|l|l|l|}
\hline Particular & $\begin{array}{l}\text { Average milk } \\
\text { without } \\
\text { shatavari } \\
\text { feeding }\end{array}$ & $\begin{array}{l}\text { Average milk } \\
\text { yield } \\
\text { shatavari feeding } \\
\text { with }\end{array}$ & $\begin{array}{l}\text { Increase in milk } \\
\text { yield duer to } \\
\text { shatavari feeding } \\
\text { (kg)/day }\end{array}$ & $\begin{array}{l}\text { Percentage } \\
\text { increased }\end{array}$ \\
\hline Buffalo & $6.20+0.20$ & $6.80+0.15$ & $0.60+0.27$ & 9.67 \\
\hline
\end{tabular}


Table.2 Economic evaluation of shatavari feeding in buffalo

\begin{tabular}{|l|l|}
\hline Parameters & Buffalo \\
\hline Extra Milk Yield (kg) & $0.60+0.27$ \\
\hline Cost of daily Shatavari feeding (Rs.) & 9.00 \\
\hline Income from extra milk (Rs.) & 21.00 \\
\hline Net Income & 12.00 \\
\hline B:C Ratio & $1: 2.28$ \\
\hline
\end{tabular}

\section{References}

Chopra, D. and Simon, D. (2000). The Chopra Center. Herbal Handbook. Three Rivers Press, New York,219: 73-75.

Krishna, L., Swarup, D. and Patra, R.C. (2005). An overview of prospects of ethano-veterinary medicine inIndia. Indian Journal of Animal Science. 75(12): 1481-1491.
Kumar, S., Mehla, R.K. and Dang, A.K. (2008). Use of Shatavari (Asparagus racemosus) as agalactopoietics and therapeutic herb- a review. Agricultural Review. 29(2): 132-138

Somkuwar, A.P. et al., (2005). Pashudhan, 31(2): 3 .

Tanwar P.S., Rathore, S.S. and Yogendra Kumar (2008). Indian J. Anim. Res., 42 (3): 232-233.

\section{How to cite this article:}

Jingar, S.C., Rachana Sharma, Pankaj Lawania, Ajesh Kumar and H.L. Bugaliya Shiv Murat Meena. 2018. Effect of Shatavari (Asparagus recemosus) on Milk Production in Lactating Buffaloes. Int.J.Curr.Microbiol.App.Sci. 7(09): 3610-3612.

doi: https://doi.org/10.20546/ijcmas.2018.709.447 